\title{
Infantile Vomiting, AE
}

National Cancer Institute

\section{Source}

National Cancer Institute. Infantile Vomiting, AE. NCI Thesaurus. Code C154942.

An adverse event in a newborn characterized by expulsion of the contents of the stomach through the mouth. 